تأثير تراكم بوته و روشهاى كنترل علفهاى هرز بر صفات رويشى و عملكرد لوبيا قرمز

محسن رشدى "، محمد كاظم عليلو `و سولماز كاظم عليلوّ

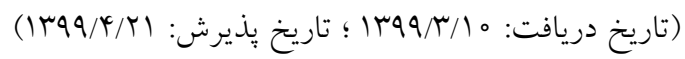

جִكيده

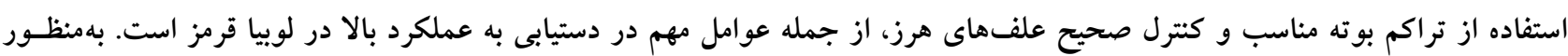

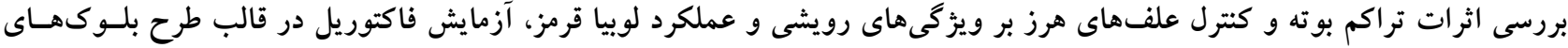

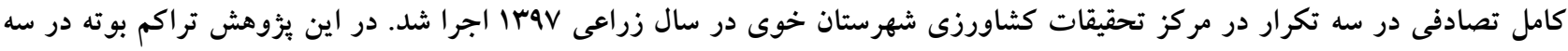

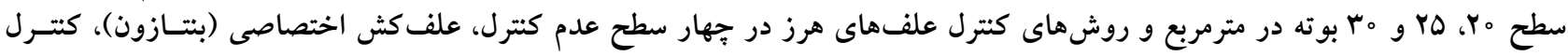

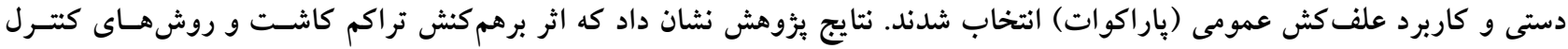

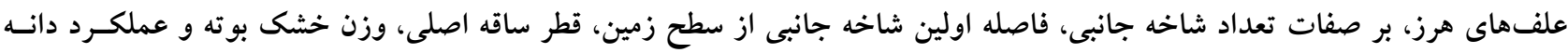

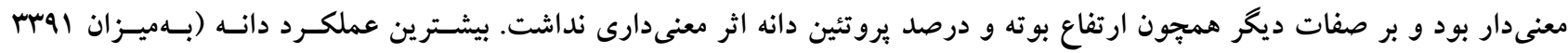

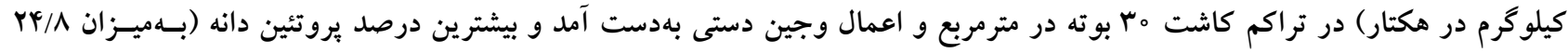

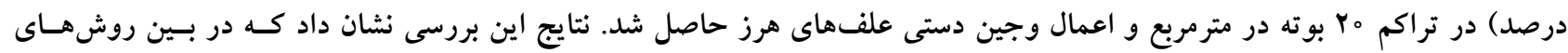

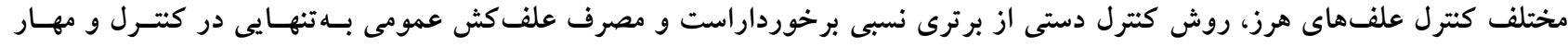

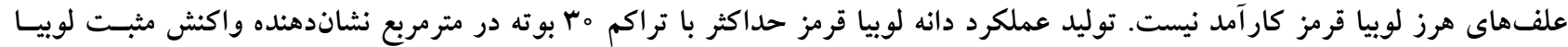

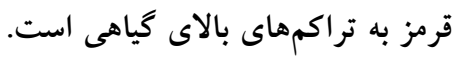

وازههاى كليدى: علف كث، درصد بروتئين، لوبيا قرمز ، قطر ساقه

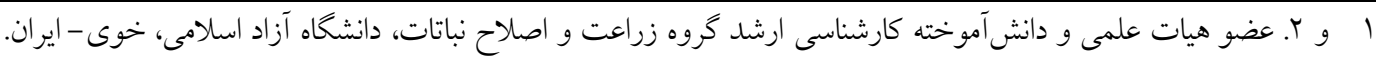

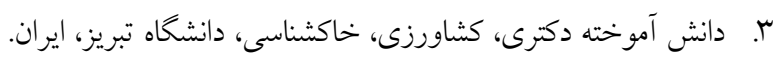

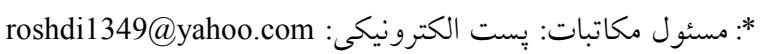


كاسته شد (Y)). در تأييد اين مطلب احمدى و همكاران (1)

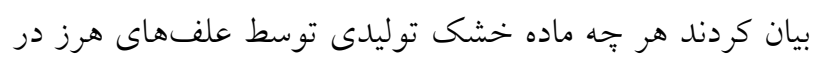

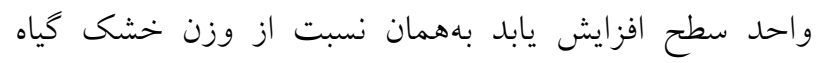

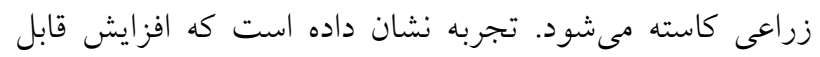

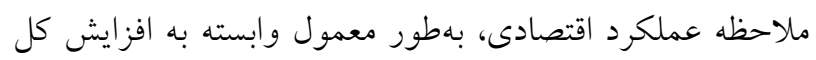

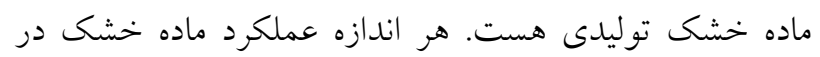

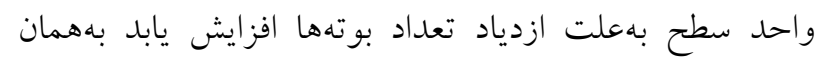

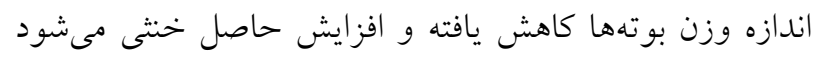
(T) (T). مطالعات مختلف نشان مىدهد كه قطر ساقه طى دوره رشدونمو تحت تأثير عوامل محيطى مختلف قرار دارد. تنظيم كنندهاى رشد (اكسين و جيبرلين)، نور، طول روز، تراكم و

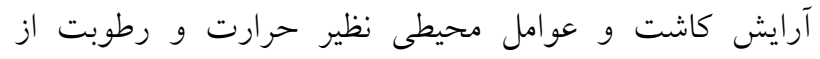

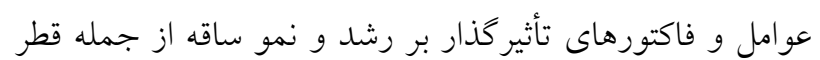

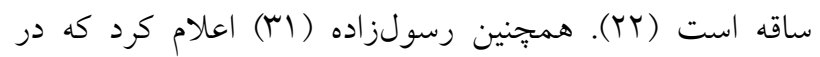

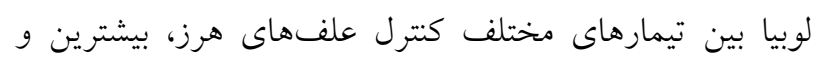
كمترين قطر ساقه بهترتيب، وجين دستى و علدم كندين علفهاى هرز بود. بهعبارتى حضور علفهاى هرز باعث وندين

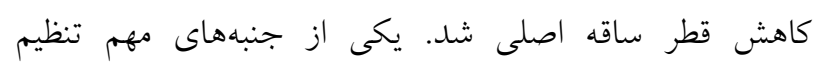

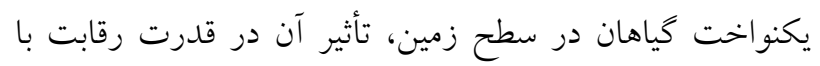

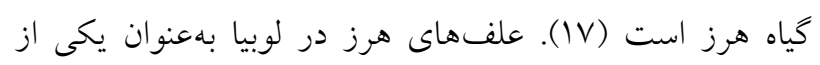

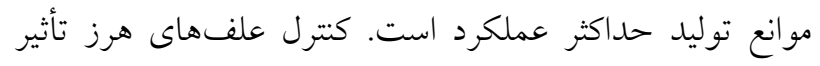

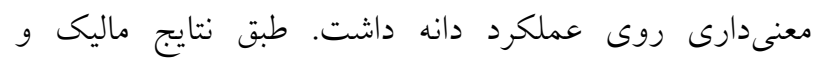

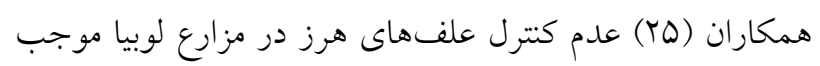

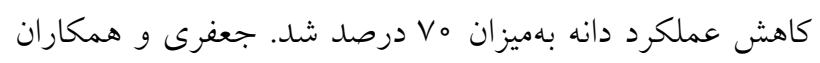

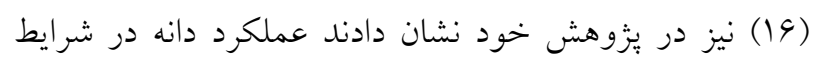

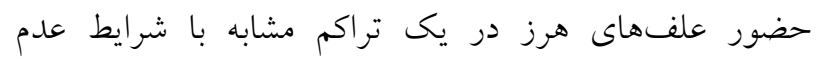
حضور علفهاى هرز، مقدار آن كمتر است. همينطور وجين هرين دستى علفهاى هرز باعث افزايش عملكرد دانه نسبت به همرئ

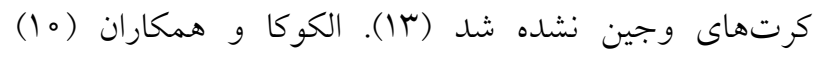
كزارش كردند رقابت علف هاى هرز در مقايسه با شر ايط وجين

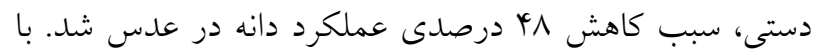
توجه به اهميت تراكم بوته در واحد سطح و همجنين

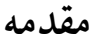

لوبيا (Phaseolus vulgaris L.) يكى از مهمترين كياهان خانواده بقولات در جهان است. اهميت حبوبات بعد از غلات

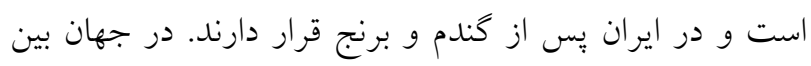

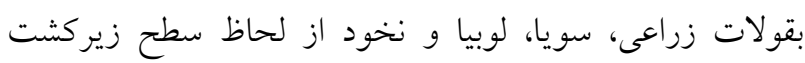

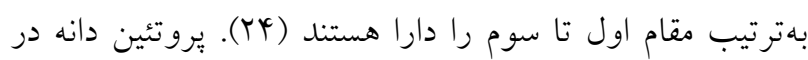

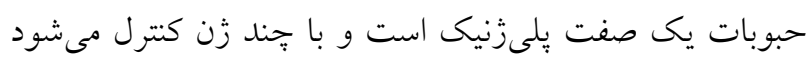

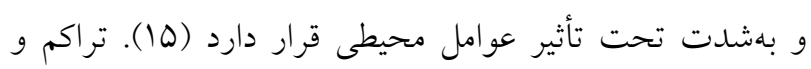

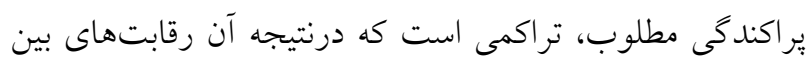

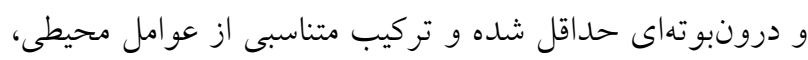

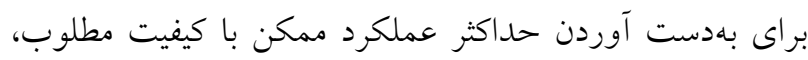
تأمين شود و در عين حال فضاى كافى براى انجام عمليات

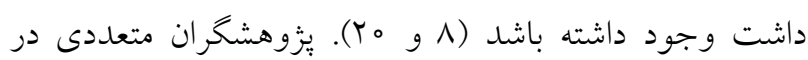

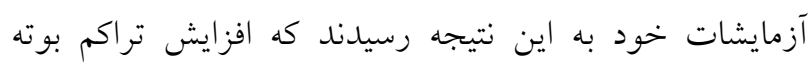

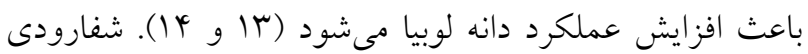
و همكاران (YY) و صالحى (سب) طى بررسى روى گياه لوبيا

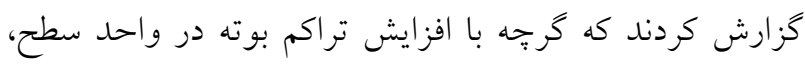
عملكرد دانه تكبوتهها كاهش مىيابد اما باعث افزايش عملكرد

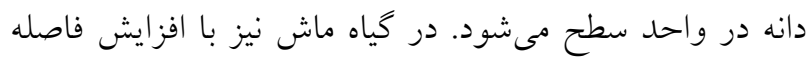

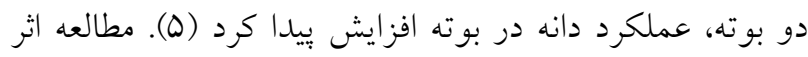

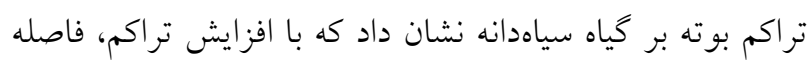

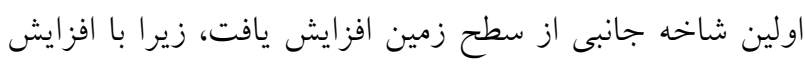

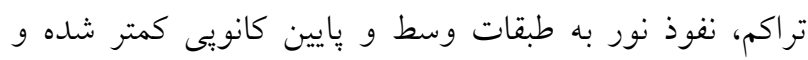

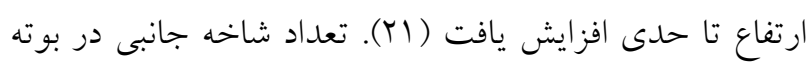

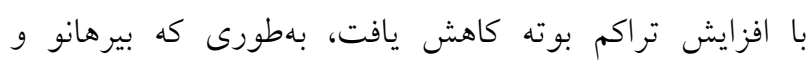

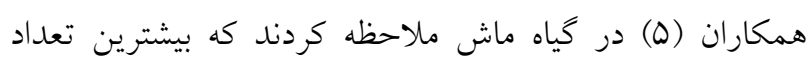

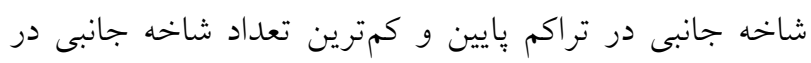
بوته مربوط به تراكم بيشتر است. همجنين در تراكم بِايين

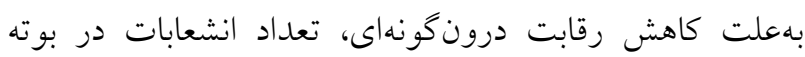

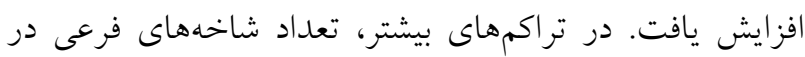

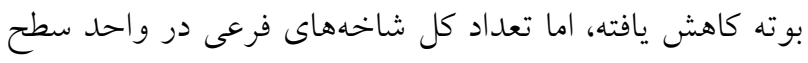

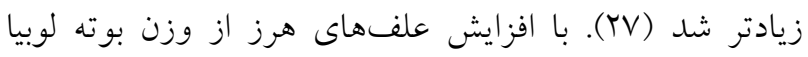


جدول ا. برخى ويزگىهاى فيزيكى و شيميايى خاك مزرعه مورد آزمايش

\begin{tabular}{|c|c|c|c|c|c|c|c|c|}
\hline $\mathrm{EC}$ & \multirow{2}{*}{$\mathrm{pH}$} & يتاسيم & فسفر & نيتروزن & CCE & ماده آلى & SP & \multirow{2}{*}{ كروه بافت } \\
\hline $\mathrm{dS} / \mathrm{m}$ & & \multicolumn{2}{|c|}{ يكى بيى ام } & \multicolumn{4}{|c|}{ (درصد) } & \\
\hline $1 / r$ & $\Lambda / 0$ & $r \% / V$ & 9 & 100 & $r \circ / l$ &.$/ 19$ & iv & لوم رسى \\
\hline
\end{tabular}

تلقيح شده با باكترىهاى ريزوبيوم لكومينوزاروم فازوئولى سويه

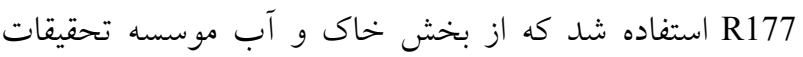
كشاورزى استان آذربايجان غربى تهيه شد. رقم سانرايز لوبيا

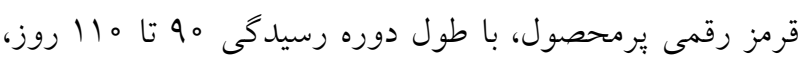

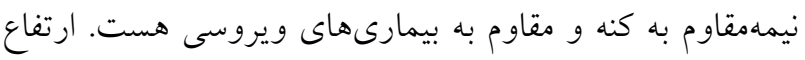

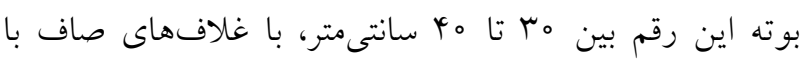

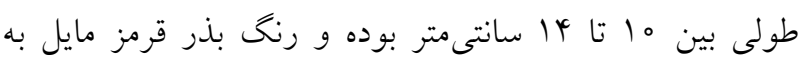

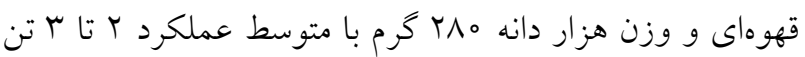

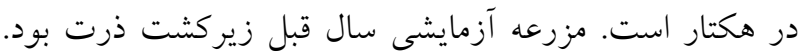
هر كرت آزمايشى داراى ^ رديف كاشت بهطول ع متر و فاصله

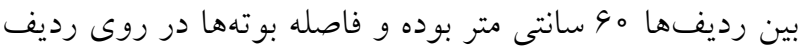
نيز برحسب سطوح فاكتور اول (تراكم بوته) بهترتيب س/N، و/N و ه/9 سانتى متر متغير بود. همجنين كنترل علفهاى هرز مطابق

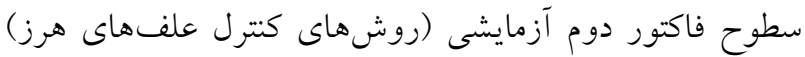
انجام كرفت. بدين ترتيب كه مصرف علفكش عمومى بعد از

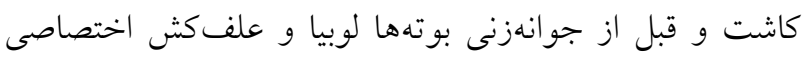

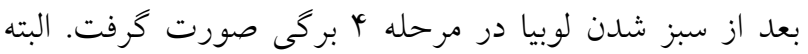

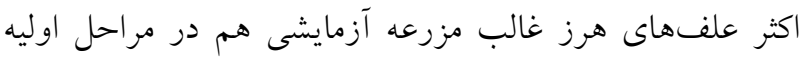

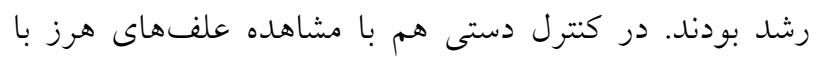

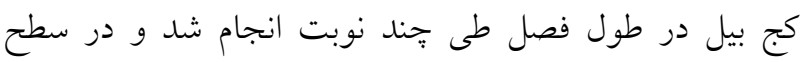

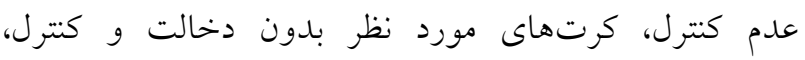

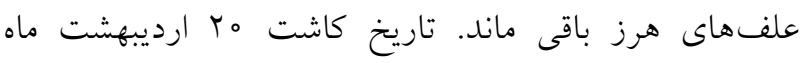
TraV

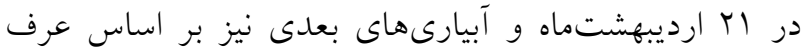
منطقه در حدود هر V-1 روز يكبار انجام گرفت. كونههاى غالب علفهاى هرز مزرعه آزمايشى بهطور عمده از يهن

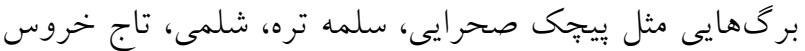
و قوزى (كنف وحشى) و نازى بركهايى مانند
تأثير علفهاى هرز بر ويزگىهاى رويشى و عملكرد لوبيا، تعيين بهترين تراكم بوته و مناسبترين روش كنترل علفهاى هرز از اهداف اصلى اين يُزوهش بود.

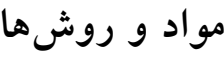

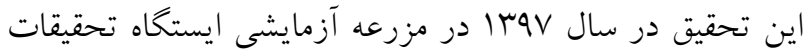
كشاورزى و منابع طبيعى شهرستان خوى واقع در r كيلومترى

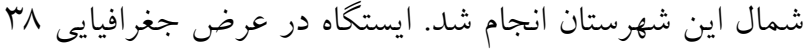

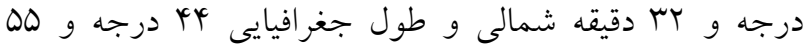
دقيقه شرقى قرار دارد و ارتفاع آن از سطح دريا IlOV متر

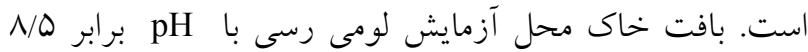

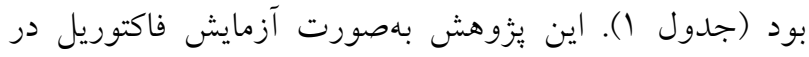

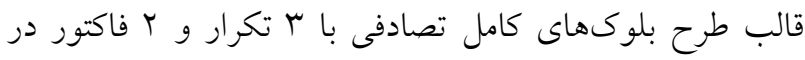
وب كرت آزمايشى اجرا شد. فاكتور اول شامل تراكم بوته لوبيا

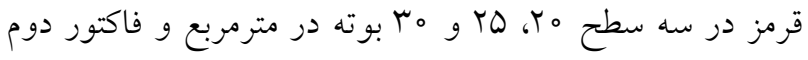

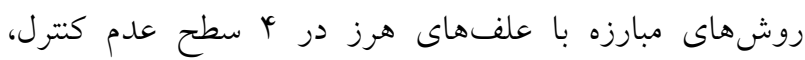

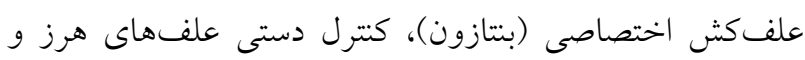
كاربرد علف كش عمومى (ياراكوات) انتخاب شد.

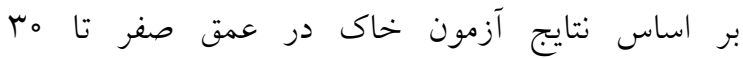

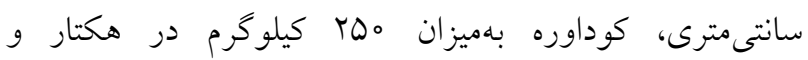
بهصورت سرى در سه مرحله مصرف شد (يك سوم قبل از

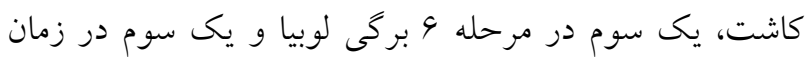

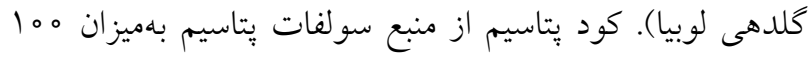

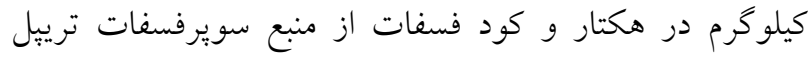

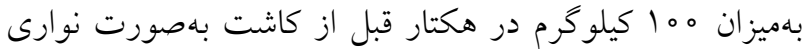
و در عمق خاك مصرف شد. در اين آزمايش براى كشت، از بذر اصلاح شده و ضدعفونى شده لوبيا قرمز رقم سانرايز 
جدول r. نتايج تجزيه واريانس صفات آزمايشى لوبيا قرمز تحت سطح مختلف تراكم بوته و روشهاى كتترل علفهاى هرز

\begin{tabular}{|c|c|c|c|c|c|c|c|c|}
\hline \multicolumn{7}{|c|}{ ميانخين مربعات } & \multirow[b]{2}{*}{ آزادى } & \multirow[b]{2}{*}{ منابع تغييرات } \\
\hline يروتئين & عملكرد دانه & وزن خشك & قطر ساقه & فاصلة اولين & تعداد شاخه & ارتفاع بوته & & \\
\hline$\circ / 1 T$ & $19 Y / 4$ & 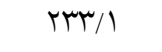 & $0 / 01$ & $0 \% 9$ & $0 / 01$ & $r / \Lambda Y$ & r & 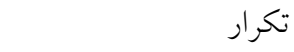 \\
\hline$\Delta / T V^{* *}$ & VQVYrVV/q** & GVYQUTV/I** & $Y / 10^{* *}$ & $1 / N^{* * *}$ & $r / r V^{* *}$ & $r \circ 9 / 9^{* *}$ & r & 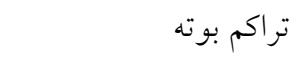 \\
\hline $1 / \Delta q^{* *}$ & $r \Delta V \circ \mu \varphi / \mu^{* * *}$ & rq1094** & $1 / 4^{* *}$ & $1 / r^{* *}$ & $1 / 4 \wedge^{* *}$ & $\Lambda N / r^{* *}$ & r & روش كنترل \\
\hline$\circ / \circ 9 r^{\mathrm{ns}}$ & $\Lambda \varphi \circ / N^{* *}$ & $Y \Psi V / \Lambda^{* *}$ & $0 / 01^{* *}$ & $\circ / Y^{* *}$ & $\circ / 10^{*}$ & $\varphi / v q^{n s}$ & 9 & تراكم بوته ×روش كنترل \\
\hline$\circ / 0 \Delta F$ & $r Q / 9$ & $\notin V / 1$ & $0 / 001$ & $0 / 001$ & $\circ / \circ r$ & $r / 90$ & rr & اشتباه آزمايشى \\
\hline $9 / 1$ & 0 & 10 & 14 & $r$ & $|V /|$ & $9 / 04$ & - & ضريب تغييرات (\%) \\
\hline
\end{tabular}

nn به ترتيب معنى دار در سطح احتمال بنج درصد، يك درصد و غير معنىدار

قرمز معنى دار شد (جدول r). بيشترين ارتفاع بوته مربوط به

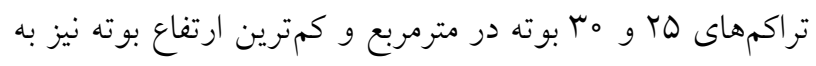

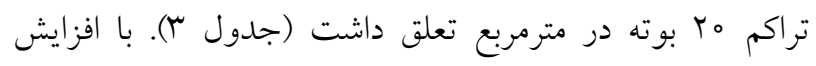

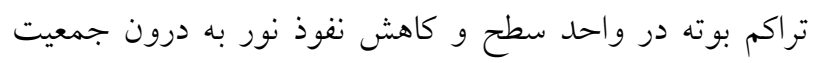

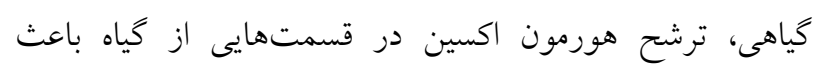

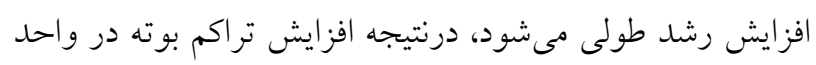

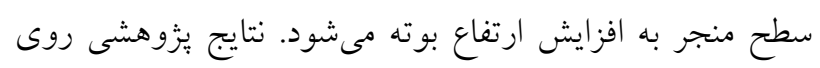

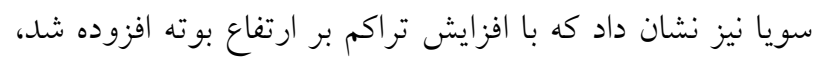

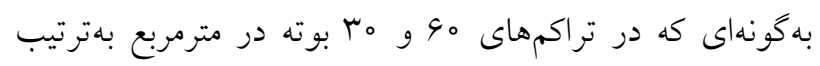
بيشترين و كمترين ارتفاع بوته بهدست آمد (19). با توجه به جدول مقايسه ميانخينها بيشترين ارتفاع بوته

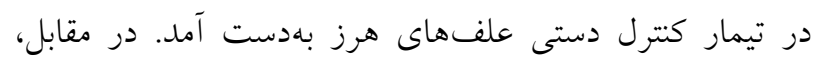

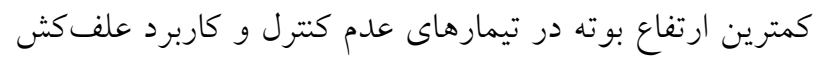

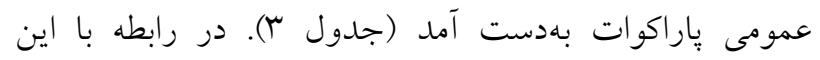

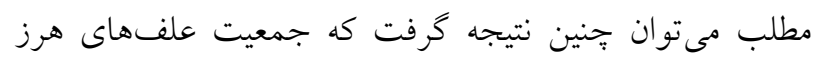

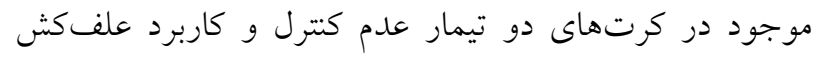

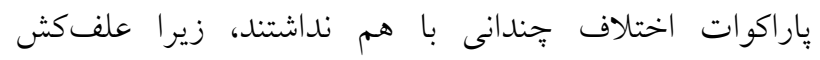
پاراكوات پِس از كاشت بذور و قبل از سبز شدن جوانهها و

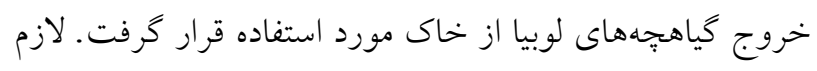

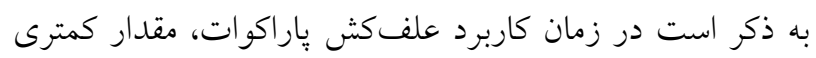

سوروف و جسبك بود. در اين آزمايش صفات ارتفاع بوته، تعداد شاخههاى جانبى، فاصله اولين شاخه جانبى از سطح إنس زمين، عملكرد دانه، قطر ساقه اصلى، وزن خشكى كل بل بوته و و

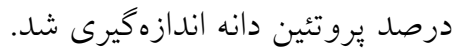

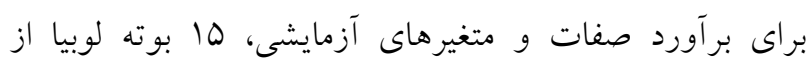

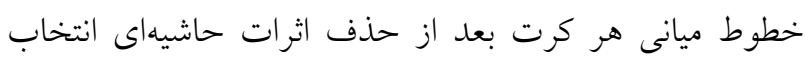

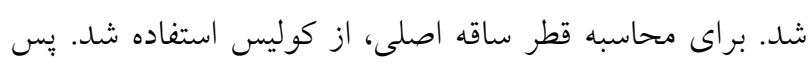

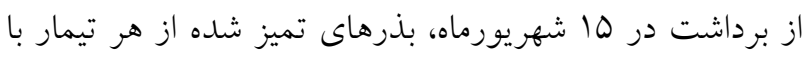

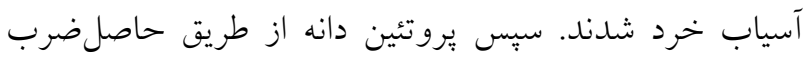

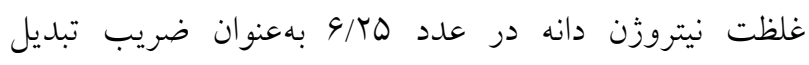
بهدست آمد. غلظت نيتروزن دانه در هر تيمار با دستخاه كجلدال

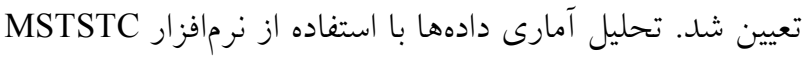

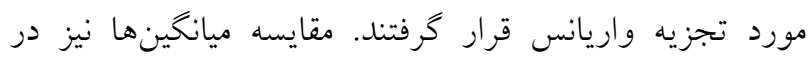
سطح احتمال ينج درصد توسط آزمون دانكن انجام و شكله هـا باسيا

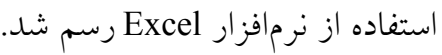

\section{نتايج و بحث

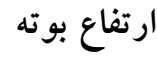

نتايج حاصل از جدول تجزيه واريانس دادهها نشان داد كه اثر تراكم بوته و روشهاى كترل علفهاى هرز بر ارتفاع بوته لوبيا 
جدول r. مقايسه ميانكين صفات آزمايشى لوبيا قرمز تحت سطوح مختلف تراكم بوته و روشهاى كنترل علفهاى هرز

\begin{tabular}{|c|c|c|c|c|c|c|c|}
\hline \multirow{2}{*}{ يرو تئين } & عملكرد دانه & وزن خشك & قطر ساقه & فاصله اولين & \multirow{2}{*}{ تعاخد } & ارتفاع بوته & \multirow{2}{*}{ تيمارهاى آزمايشى } \\
\hline & \multicolumn{2}{|c|}{ (كيلو گرم در هكتار) } & (ميلى متر) & (سانتى متر) & & (سانتى متر ) & \\
\hline & & & & & & & تراكم بوته \\
\hline$r Y / T^{a}$ & T9940 & grra & $q / q^{a}$ & $r / N \mu^{c}$ & $r / v y^{a}$ & $r G / \Lambda^{c}$ & •lY بوته در مترمربع \\
\hline$r \mu / \Lambda^{b}$ & rarrbb & $90 \mathrm{~V}{ }^{\mathrm{b}}$ & $\Delta / a r^{b}$ & $\varphi / \Lambda \Lambda^{b}$ & $r / 19^{b}$ & 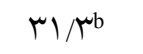 & هT بوته در مترمربع \\
\hline$r T / q^{c}$ & MAra & qNIT"a & $\Delta / \Delta \varphi^{c}$ & $\varphi / \Delta y^{\mathrm{ca}}$ & T/GYC & $r 4 / 9^{a}$ & ما بوته در مترمربع \\
\hline & & & & & & & روش كنترل \\
\hline$r \mu / \mu^{c}$ & $r V I r^{d}$ & stord & $\Delta / \Delta \Delta^{d}$ & r/9 سa & $r / \Lambda \mu^{c}$ & $r \Lambda / V^{c}$ & عدم كنترل \\
\hline$r \mu / V^{b}$ & r०Hץb & $9990^{\mathrm{b}}$ & $q / \Lambda \mu^{\mathrm{b}}$ & $\Gamma / \Lambda \Lambda^{c}$ & $\Gamma / \mu \Lambda^{b}$ & bro & \\
\hline$r Y / T^{a}$ & Mera & $9 \wedge \cdot 1^{\mathrm{a}}$ & $9 / \pi q^{a}$ & $r / N \mu^{d}$ & r/9 pa & $r \Delta / \wedge^{a}$ & كنترل دستى \\
\hline Tr/Kbc & $r \wedge \circ \varphi^{c}$ & $9400^{\circ}$ & $\Delta / V \omega^{c}$ & $\varphi / \mu y b$ & $r / V q^{c}$ & $r q / \Lambda^{c}$ & علف كش پِراكوات \\
\hline
\end{tabular}

ميانخين هاى داراى حروف مشابه در هر ستون فاقد تفاوت معنىدار در سطح احتمال ينج درصد با آزمون دانكن هستند.

كياه در اثر رقابت بيان شده است (rr). با توجه به رقابت ضعيف لوبيا و اثر غالب علفهاى هرز بر اين گياه، افت قابل توجه ارتفاع بوته لوبيا قرمز در تيمار عدم كتترل علفهاى هرز مشاهده شد، كه اين ضرورت استفاده از روشهاى مختلف و بهينه براى كنترل علف هاى هرز در زراعت لوبيا قرمز را آشكار مىسازد. اثر برهمكنش تراكم بوته و روشهاى مختلف كنترل علفهاى هرز بر ارتفاع بوته اثر معنىدارى نداشت (جدول r). بهعبارتى ديخر سطوح فاكتورهاى آزمايشى بهطور مستقل از هم عمل كرده و تأثيرى روى يكديخر نداشتهاند.

تعداد شاخه جانبى در بوته اثر تراكم بوته و روشهاى كتترل علفهاى هرز بر تعداد

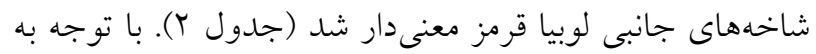

از علفهاى هرز در مزرعه سبز شده بودند كه اين خود دليل مشخصى براى اختلاف ناجيز ميانخين ارتفاع بوته بين دو تيمار مذكور مىتواند باشد.

طبق يافتههاى قمرى و احمدوند (11) ارتفاع بوته با افزايش طول دوره تداخل علفهاى هرز كاهش و با افزايش طول دوره كنترل افزايش يافت. بهطورى كه در تيمار عدم كنترل در مقايسه با ساير تيمارها لوبيا قرمز از ارتفاع كمترى برخوردار بود. در منابع گزارشهاى متناقضى در رابطه با اثر رقابت علفهاى هرز بر ارتفاع گياهان زراعى وجود دارد. كاورماسى و همكاران (1) كزارش كردند كه افزايش رقابت علف كهاى هرز، ارتفاع بوته باقلا را كاهش داد. در مقابل، ويليامز و ليندكوئيست (ظN) افزايش ارتفاع بوته شد. افزايش نسبت نور مادون قرمز نسبت به نور قرمز بهعلت سايهاندازى علفهاى هرز، دليل افزايش ارتفاع 
اثر برهم كنش تراكم بوته و روشهاى كنترل علفهاى هرز بر

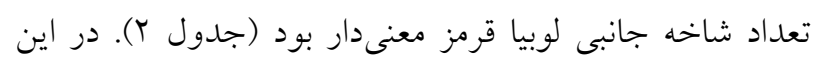

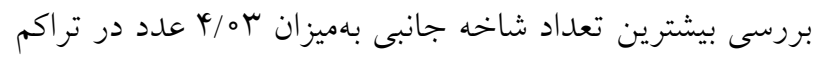

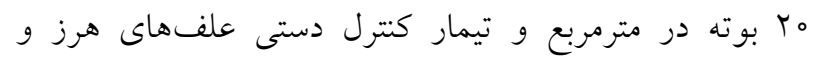

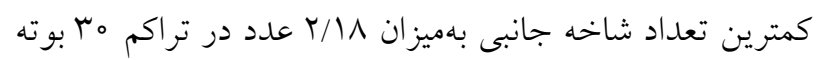
در مترمبع و تيمار عدم كتترل علفهاى هرز مشاهده شد

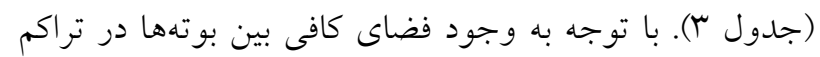

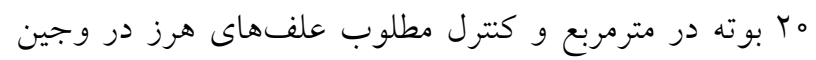

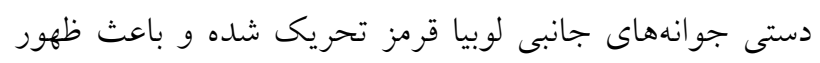

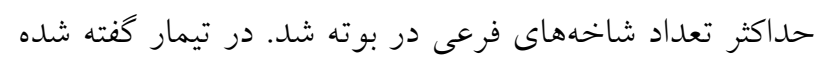

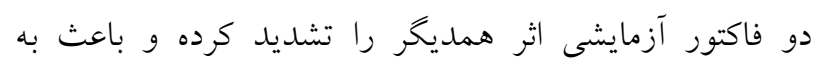

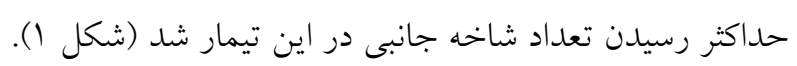

فاصله اولين شاخه جانبى از سطح زمين

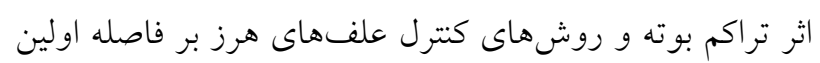

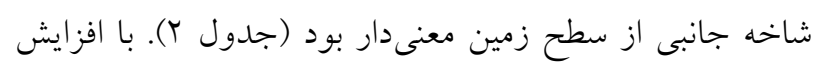

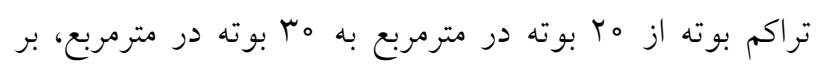
فاصله اولين شاخه جانبى از سطح زمين افزوده شد. بيشترين

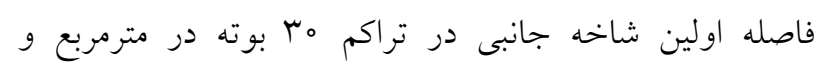

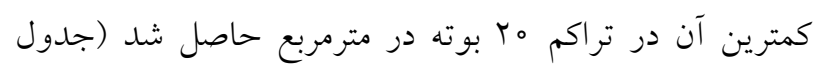

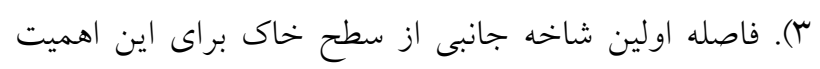

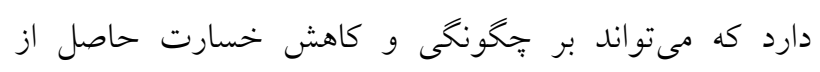

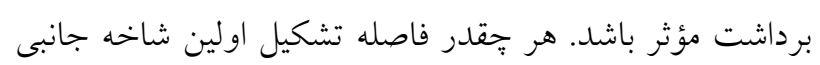

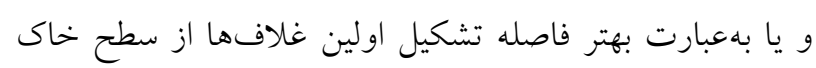

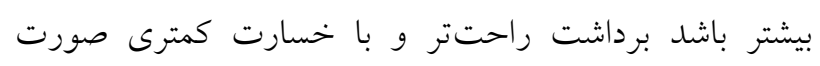

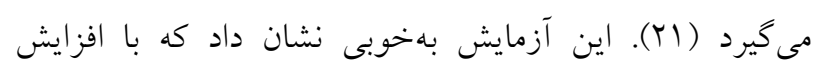

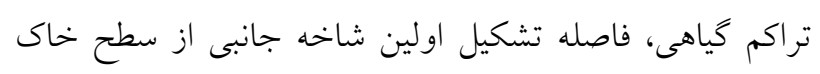

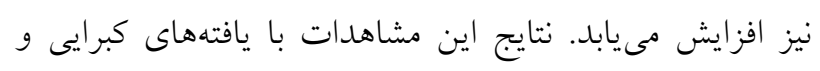

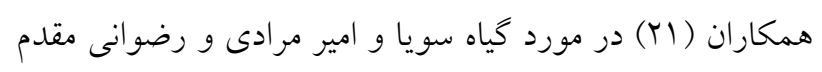

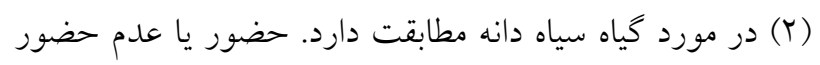

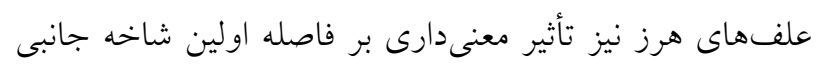

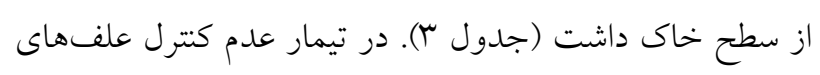

جدول مقايسه ميانخينها بيشترين تعداد شاخههاى جانبى در

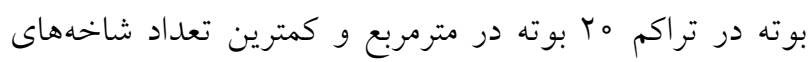

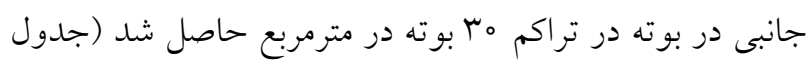

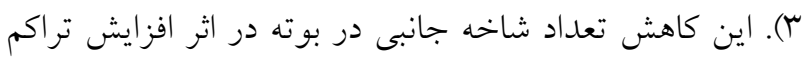

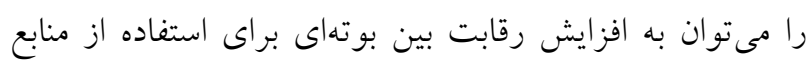

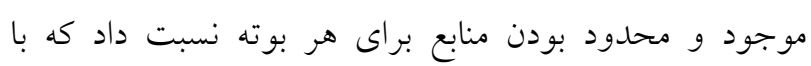

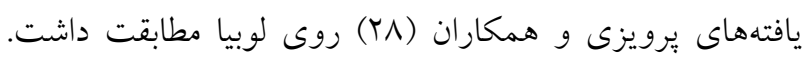

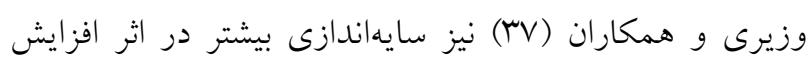

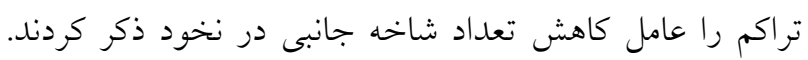

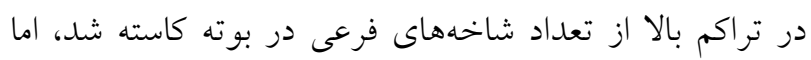

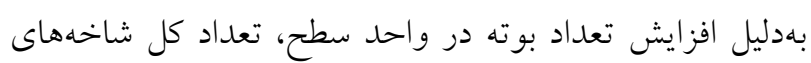

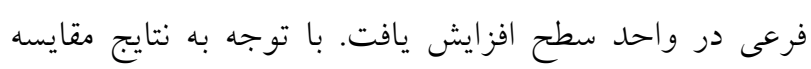

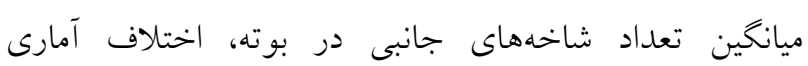

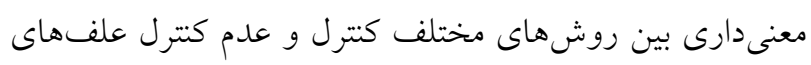

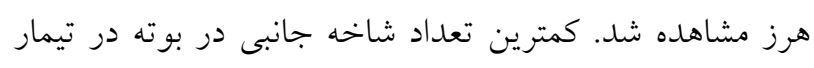

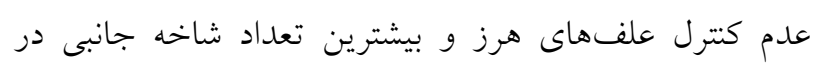

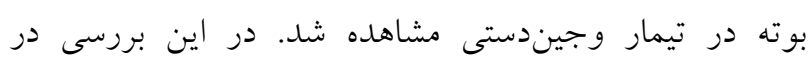

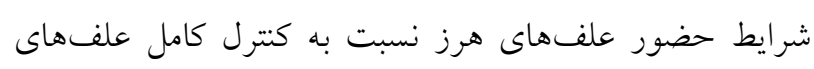

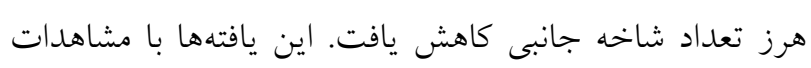

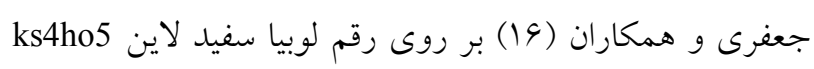

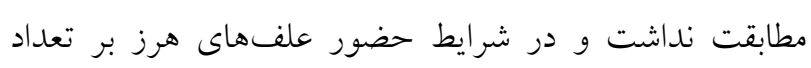

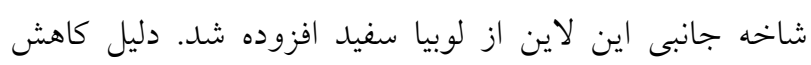

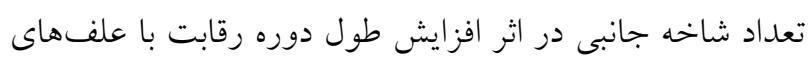

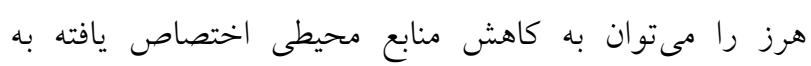

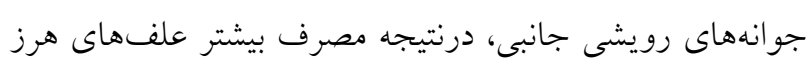

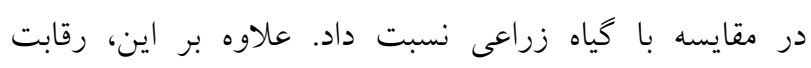

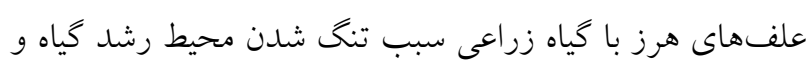

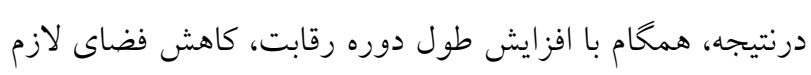
براى توليد شاخههاى فرعى توسط كياه دانست. كاهش تعداد

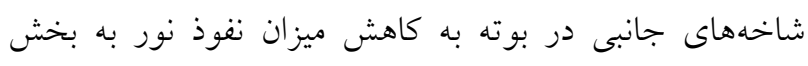

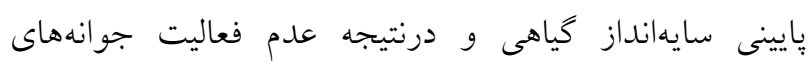

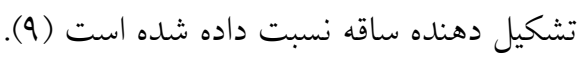




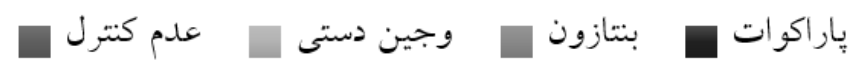

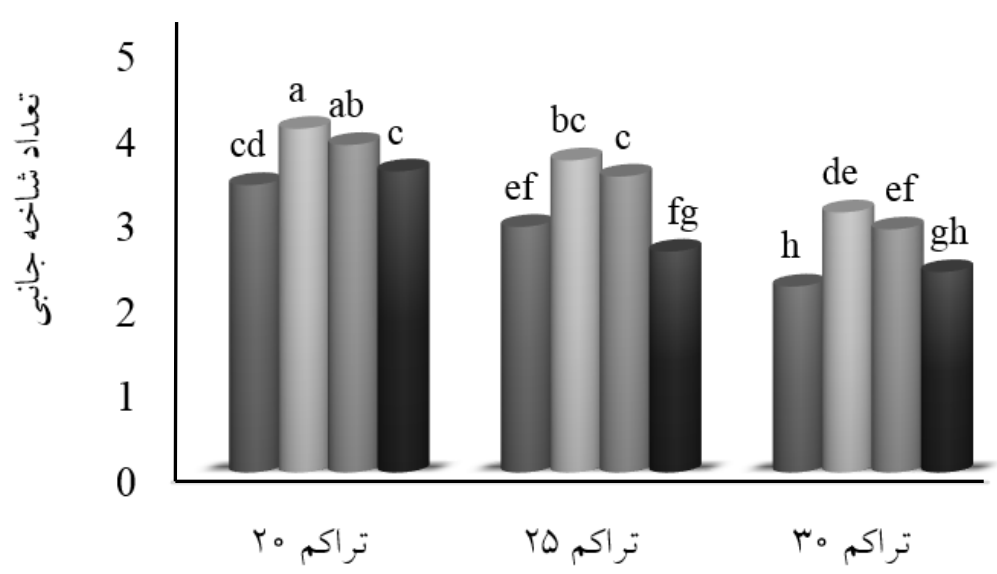

شكل ا. اثر برهم كنش سطوح مختلف تراكم و روشهاى كنترل علفهاى هرز بر تعداد شاخه جانبى در بوته

(حروف مشترك در هر ستون فاقد تفاوت معنى دار بر اساس آزمون دانكن در سطح احتمال ينج درصد است.

جدول F. ضرايب همبستخى صفات مورد مطالعه لوبيا قرمز

\begin{tabular}{|c|c|c|c|c|c|c|}
\hline عملكرد دانه & وزن خشك بوته & قطر ساقه & فاصله اولين شاخه & تعداد شاخه & ارتفاع بوته & \\
\hline & & & & & $-0 / r q 4$ & تعداد شاخه \\
\hline & & & & $-0 / 94 \varphi^{* *}$ & $0 / 109$ & فاصله اولين شاخه \\
\hline & & & $-0 / 9 \mu r^{* * *}$ & $\circ / 944^{* *}$ & $-0 / T$ & قطر ساقه \\
\hline & & $-\circ / \Delta \Delta$ & $0 / r$ & $-0 / 101$ & $\circ / 9 \vee \Lambda^{* *}$ & وزن خشك بوته \\
\hline & $\circ / 999^{* *}$ & $-0 / / T V$ & -NV & - & $\circ / 99^{* *}$ & عملكرد دانه \\
\hline O/TAK & $-0 / 19 V$ & $\circ / 9 r^{* *}$ & $-0 / 911^{* *}$ & - & - & درصد يروتئين \\
\hline
\end{tabular}

هرز بيشترين فاصله اولين شاخه جانبى از سطح زمين و كمترين بر فاصله اولين شاخه جانبى از سطح زمين معنىدار بود (جدول

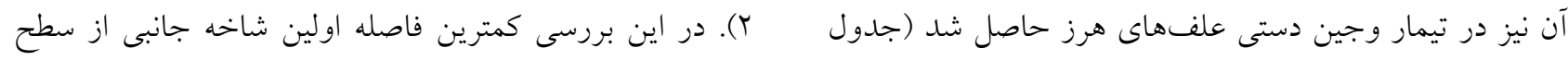

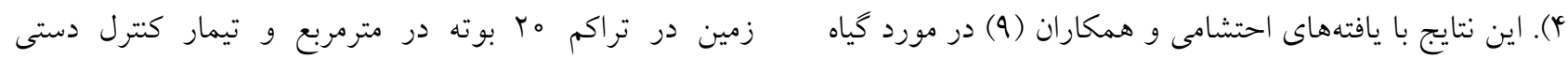

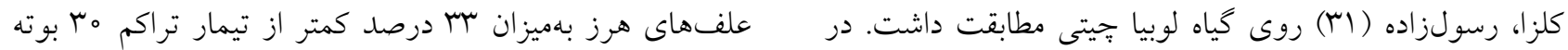

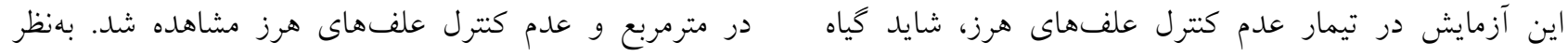

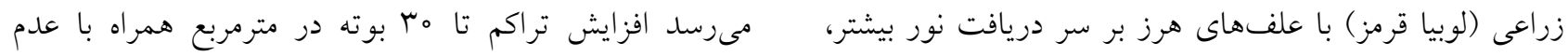

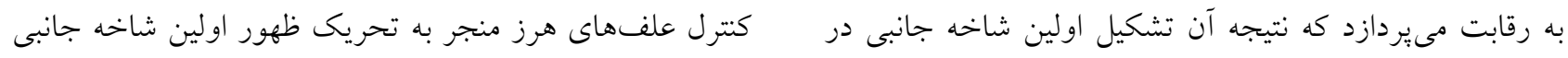

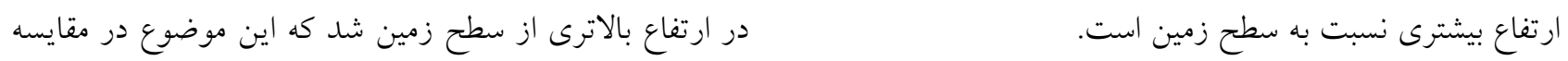

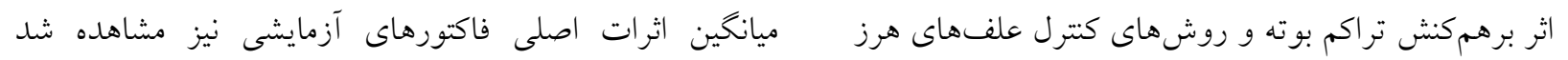


جيتى مطابقت داشت. جنين بهنظر مىرسد كه حضور علفهاى هرز و ايجاد رقابت بين كياه زراعى و علف هرز، از منابع محيطى اختصاص يافته به كياه زراعى (لوبيا قرمز) كاسته شده و موجب كاهش قطر ساقه اصلى شده است. قطر ساقه اصلى تحت تأثير اثر برهمكنش دو فاكتور آزمايشى معنى دار شد (جدول r). در اين بررسى بيشترين قطر

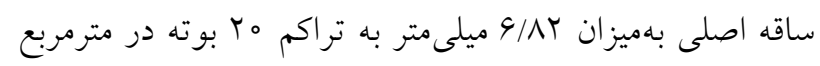
و كنترل دستى علفهاى هرز و كمترين قطر ساقه اصلى بهميزان

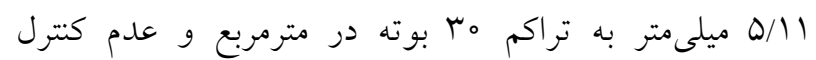
علفهاى هرز تعلق گرفت (شكل r- بـ).

\section{وزن خشك كل بوته} اثر تراكم بوته و روشهاى كنترل علفهاى هرز بر وزن خشى تر بوته، معنىدار شد (جدول Y). با توجه به مقايسه ميانخينها، بيشترين بيوماس كياهى مربوط به تراكم مب بوته در مترمربع و

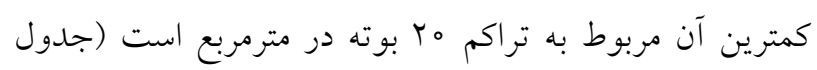
س). وزن خشك كياه يكى از عوامل مهم در برآورد عملكرد است و بيانكر ميزان بهرهذيرى جامعه گياهى از تابش نور خورشيد طى فصل رشد است. با توجه به ارتباط مستقيم بين جذب تابش و شاخص سطح برى، افزايش تراكم باعث افزايش شاخص سطح برى و جذب تابش بيشترى مىشود كه در نتيجه آن مواد فتوسنتزى افزايش يافته و منجر به افزايش عملكرد

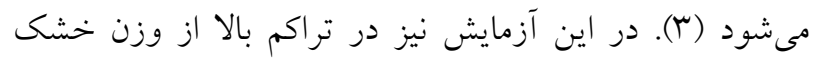
تكبوته كاسته شد، اما جون تعداد بوته در واحد سطح افزايش يافت، بر وزن خشك كل بوته در هكتار افزوده شد. بهنظر مىرسد دادههاى يزوهش حاضر در مورد اين صفت با نتايج آزمايش وزيرى و همكاران (rV) مطابقت داشت. بر اساس جدول مقايسه ميانخينها، بيشترين وزن خشك بوته در تيمار كنترل دستى علفهاى هرز با V درصد برترى نسبت به عدم

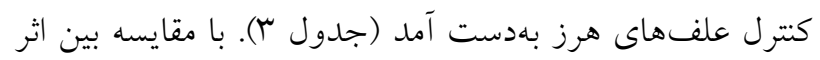
دو علفكش بنتازون و يُاراكوات بر وزن خشك بوته مشخص شد كه ميزان وزن خشك بوته در تيمار علف كش بنتازون
(جدول r). كاهش فاصله بوتهها روى رديف و عدم مبارزه با علفهاى هرز ممكن است باعث كاهش دريافت نور داخل كانويى و تشديد رقابت بين بوتهاى شود كه اين مسئله در افزايش فاصله تشكيل اولين شاخه جانبى از سطح زمين در تيمار اخير (تراكم مب بوته و عدم كتترل علفهاى هرز) مؤثر واقع شد (شكل r- الف)

\section{قطر ساقه اصلى}

اثر تراكم كاشت و روشهاى كنترل علفهاى هرز بر قطر ساقه

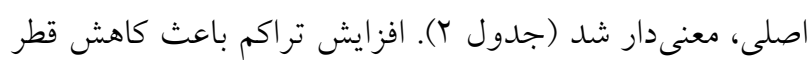
ساقه اصلى شد، بهطورى كه بيشترين قطر ساقه به ميزان وس 9 ميلىمتر در تراكم م T بوته در مترمربع و كمترين قطر ساقه بهميزان وه/ه ميلى متر در تراكم هب بوته در متر مربع حاصل شد (جدول r). دليل كاهش قطر ساقه در تراكمهاى بالا افزايش رقابت درونگونهاى است كه طى آن گياهان براى جذب نور بيشتر بر ارتفاع ساقه خود افزوده و با توجه به محدوديت مواد فتوسنتزى توليدى، افزايش ارتفاع ساقه در تراكمهاى بالا با كاهش قطر ساقه همراه است. همجنين با افزايش تراكم بوته، نورى كه به كف كانويى مىرسد كم شده و رقابت بين اندامهاى كياه براى جذب بيشتر تشعشع زياد شده و از طرف ديخر تخريب نورى اكسين صورت نمى گيرد كه مجموعه اين عوامل مىتواند باعث افزايش طول ميانگرهها، افزايش ارتفاع بوته و كاهش قطر ساقه شود (r). در گياه نخود فرنكى نيز كاهش تراكم و افزايش فضا براى رشد بوتهها باعث شد بوتهها قطر

ساقه بيشترى داشته باشند (1).

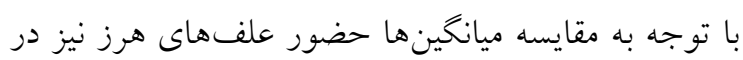
سطح احتمال يك درصد قطر ساقه را تحت تأثير قرار داد. در اين بررسى حضور علفهاى هرز باعث كاهش قطر ساقه اصلى شد. بيشترين اندازه قطر ساقه بهميزان وه/ 9 ميلىمتر در تيمار وجين دستى علفهاى هرز و كمترين اندازه قطر ساقه بهميزان ه/ه ميلى متر در تيمار عدم كنترل علفهاى هرز مشاهده شد (جدول r). اين نتايج با يافتهاى رسولزاده (اس) در مورد لوبيا 


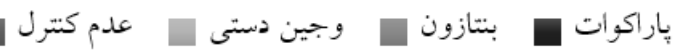

بتتازون صـ وجين دستى صـ عدم كترل

باراكوات
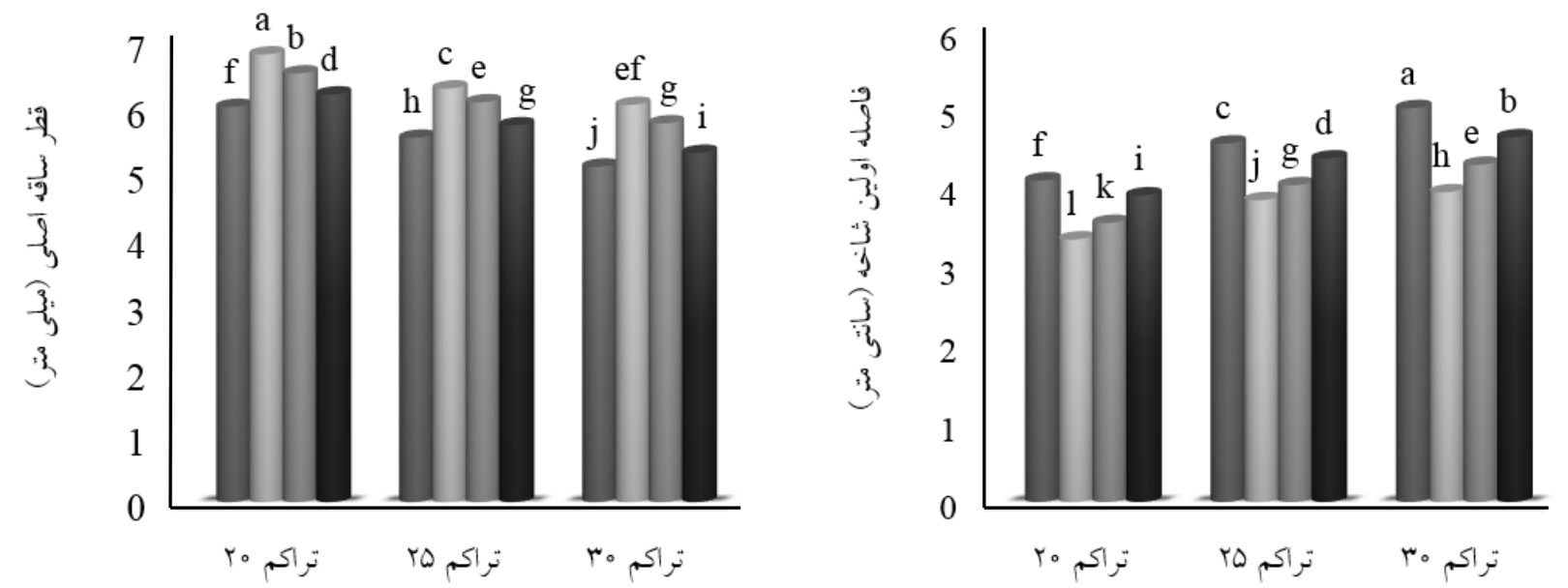

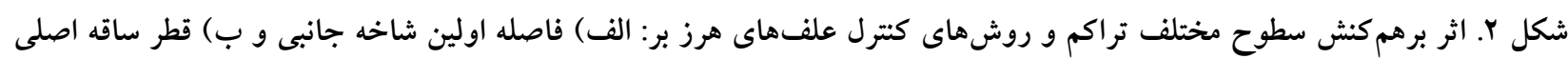

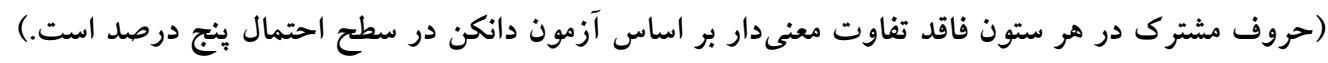

ץ درصد بيشتر از تيمار علفكش ياراكوات بود (جدول r). بود (شكل r- الف).

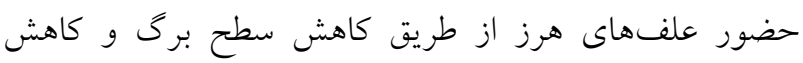

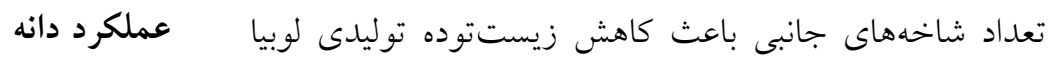

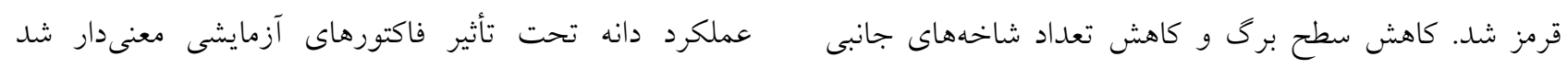

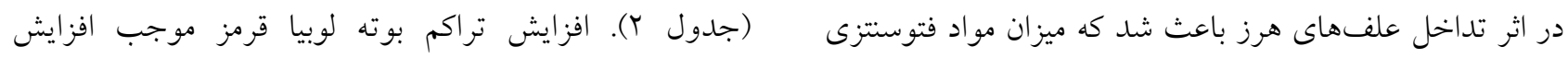

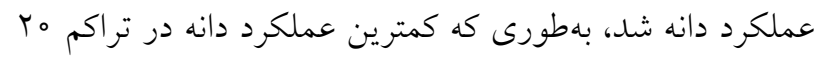

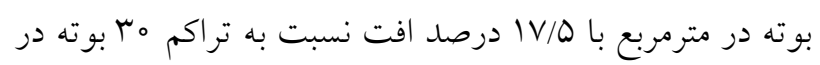

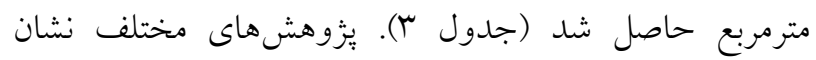

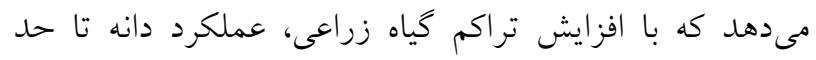

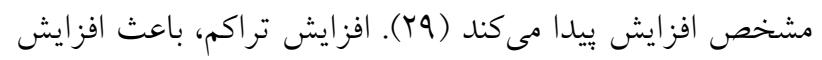

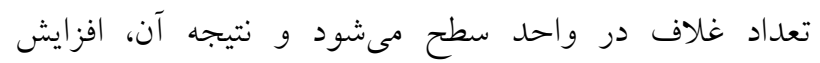
عملكرد دانه است. ارقام رشد محدود حبوبات، به تغييرات تراكم و فاصله رديف كاشت واكنش بهتر نشان داده و براى كاشت در تراكم هاى بالا (فواصل رديف كاشت باريك) ردئ از ارقام رشد نامحدود، مناسبتر هستند كه شايد تشكيل بخش عمده

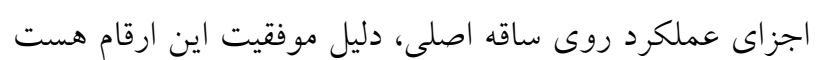

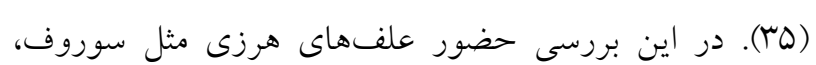
جّبك، سلمه تره و يِيجى صحر ايى باعث كاهش عملكرد دانه

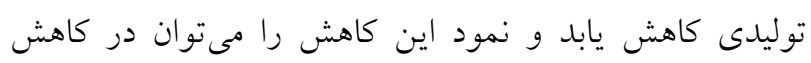
وزن خشك برى، ساقه، شاخههاى جانبى و كل لوبيا دانست.

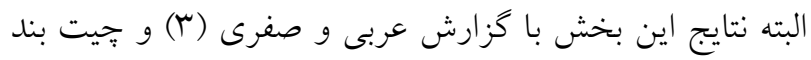

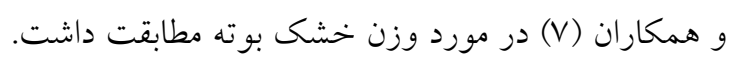

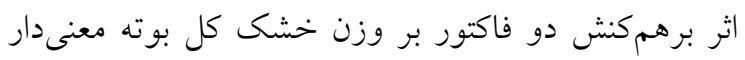

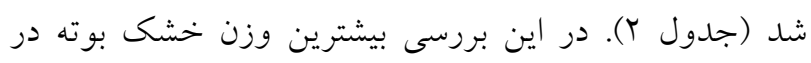

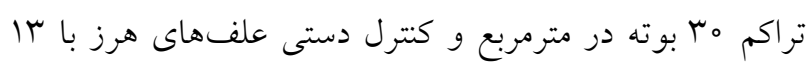

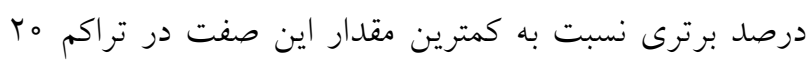

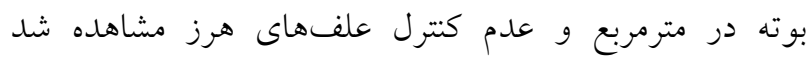

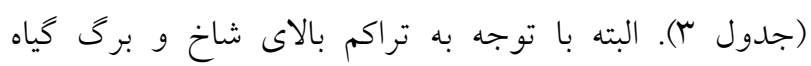

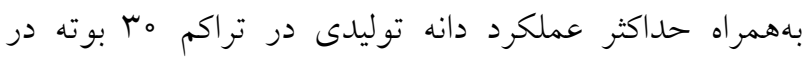

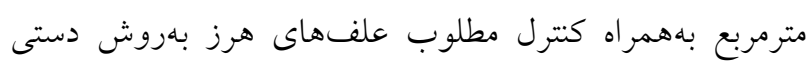

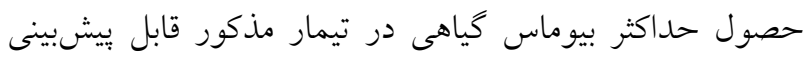



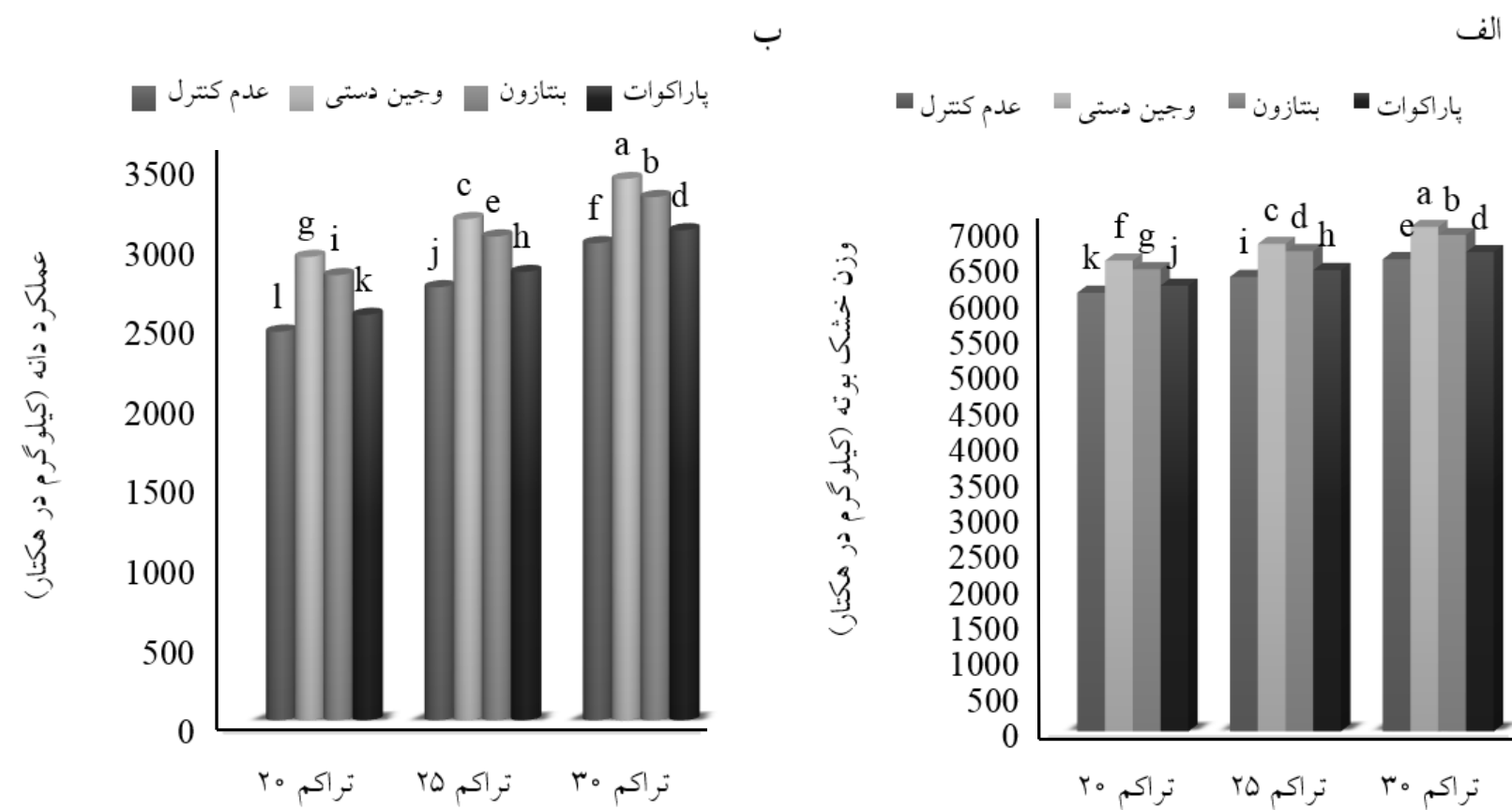

شكل r. اثر برهم كنش سطوح مختلف تراكم و روشهاى كنترل علفهاى هرز بر: الف) وزن خشك بوته و ب) عملكرد دانه

(حروف مشترى در هر ستون فاقد تفاوت معنىدار بر اساس آزمون دانكن در سطح احتمال ينج درصد است.)

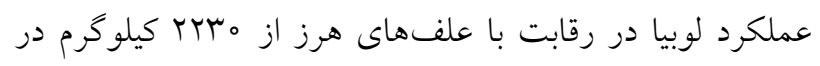

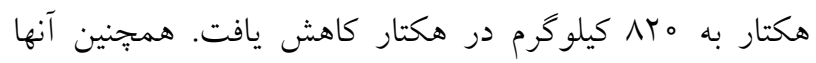

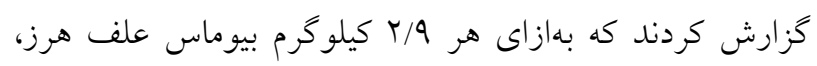

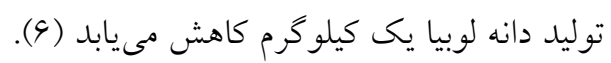
اثر برهم كنش تراكم بوته و روشهاى كتترل علف هاى هرئ هرز

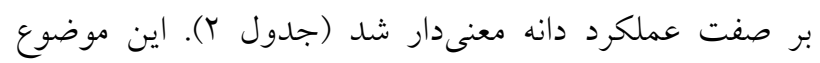
حاكى از تشديد اثرات سطوح فاكتورهاى آزمايشى بر همديخر داني

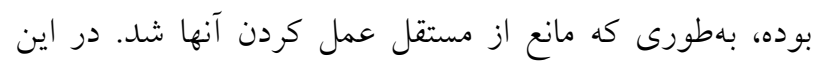

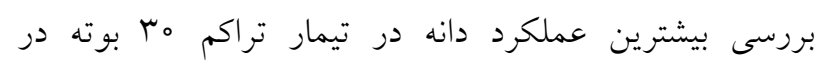

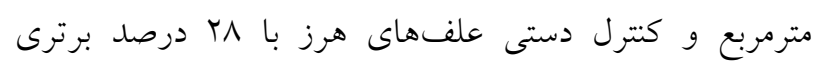

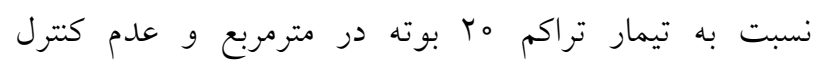

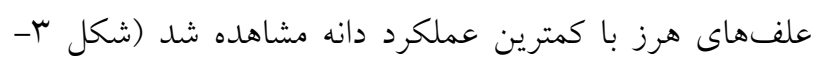

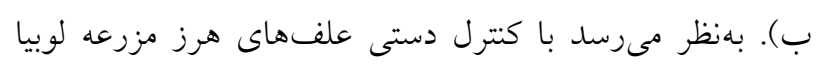

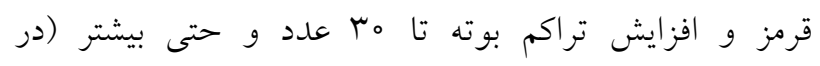

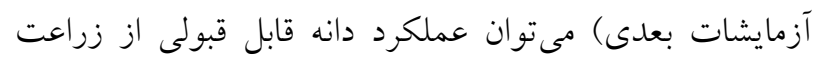

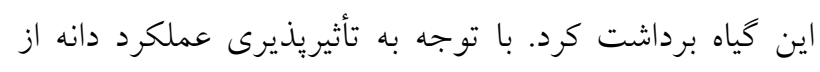

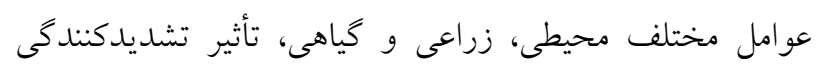

شد. بيشترين عملكرد دانه در تيمار وجين دستى و كمترين

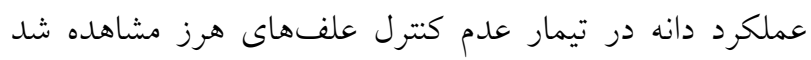

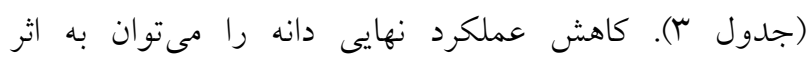
نامطلوب علفهاى هرز بر كياه زراعى از طريق كاهش منابع

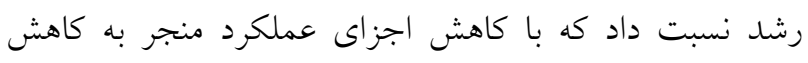

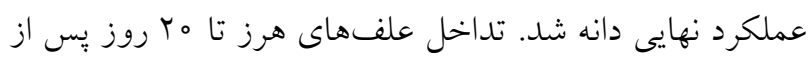

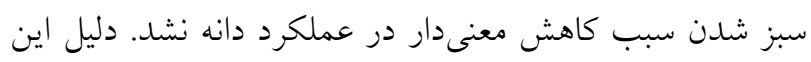

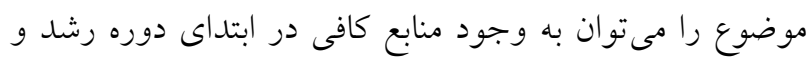

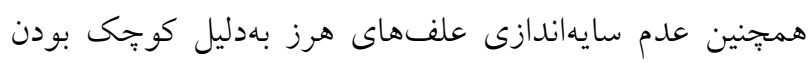

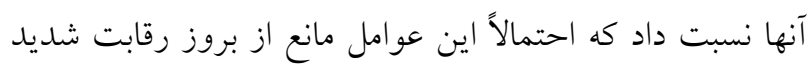

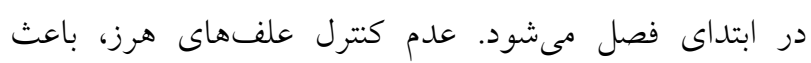

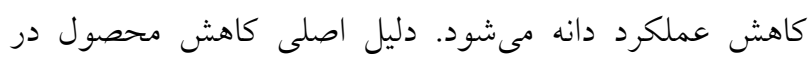

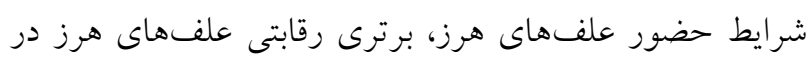

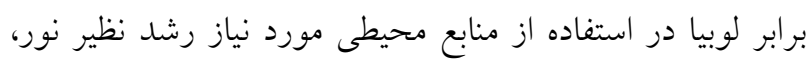

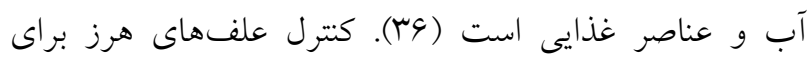
بهدست آوردن عملكرد بالا ضرورى است. يُزوهشكر ان بان با تأكيد

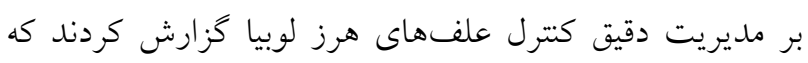


فصل رشد بهدليل كوجكى بوتهها احتمالاً رقابت اندى بين

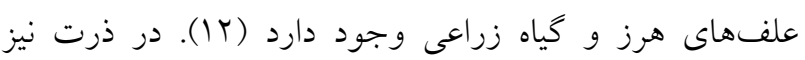

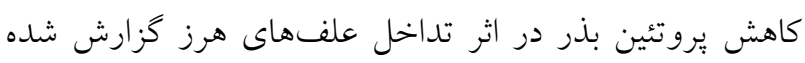

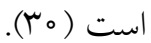

اثر برهم كنش تراكم بوته و روشهاى كترل علفهاى هرز

براى درصد يروتئين دانه معنىدار نشد (جدول r). سطوح

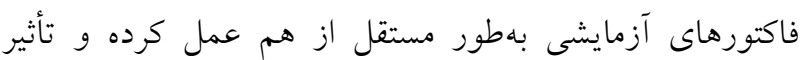
معنى دارى روى يكديخر از لحاظ اين صفت آزمايشى نداشتند. بهعبارتى ديكر سطوح دو فاكتور از لحاظ درصد يروتئين دانه اثر همديخر را خنثى كردند.

همبستگى صفات

بررسى ضرايب همبستخى مربوط به صفات آزمايشى، بيانخر

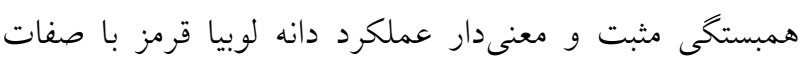

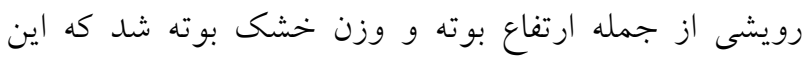

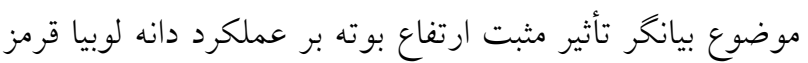

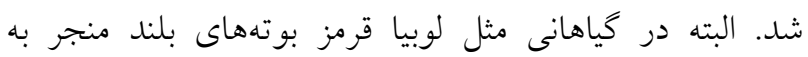

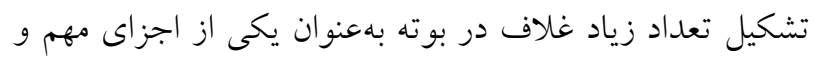
مؤثر عملكرد دانه هست. ضمناً رابطه مثبت و معنى دار عملكرد دانه با وزن خشى كل بوته (بيوماس) حاكى از سرمايه كذارى مطلوب كياه روى بخشهاى اقتصادى و تخصيص مواد فتوسنتزى مطلوب به اجزاى زايشى از جمله دانه هست (جدول

\section{نتيجه گيرى}

در اين آزمايش، اثر منفى افزايش تراكم بر كاهش عملكرد

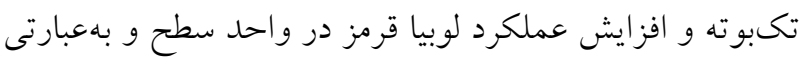

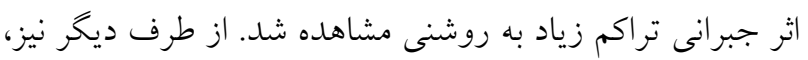

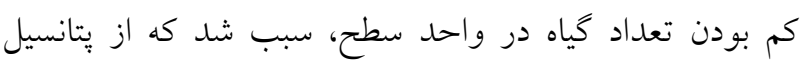

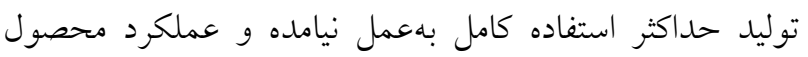
كاهش يابد. علفهاى هرز از طريق رقابت بر سر منابع غذايى، بـاني

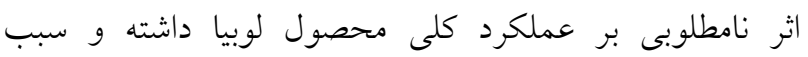

كنترل علفهاى هرز و تراكم بوته بر عملكرد دانه لوبيا قرمز

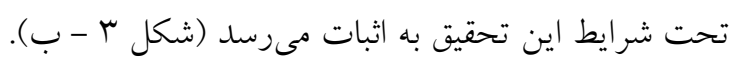

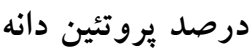
اثر تراكم بوته و روشهاى كنترل علفهاى هرز، بر درصد

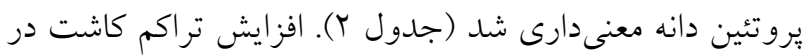
واحد سطح موجب كاهش درصد يروتئين دانه شد، بهطورى كه تئر

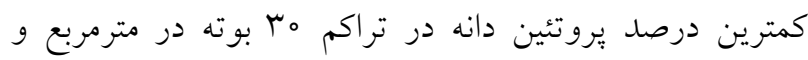

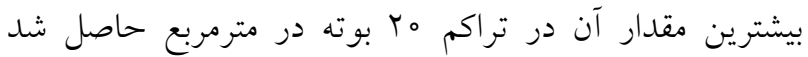

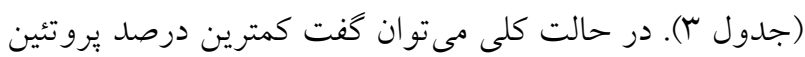
دانه در بالاترين تراكم كاشت و بيشترين درصد يروتئين دانه در پايينترين تراكم كاشت بهدست آمد. در واقع با افزايش تراكم

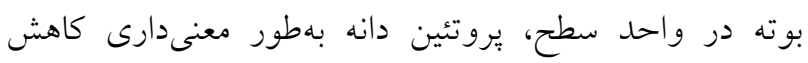

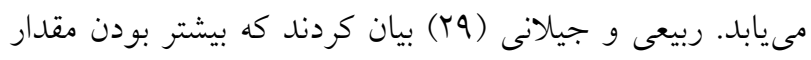

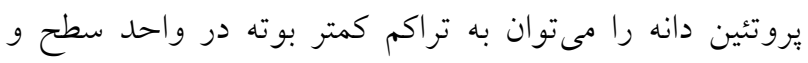

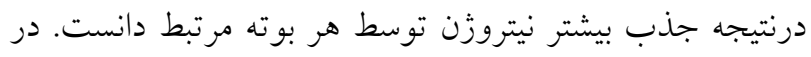

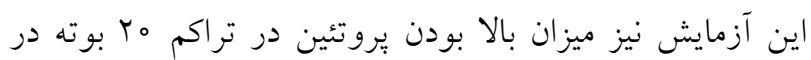

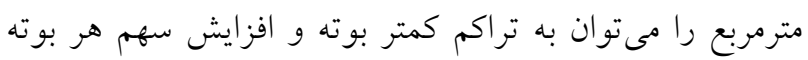

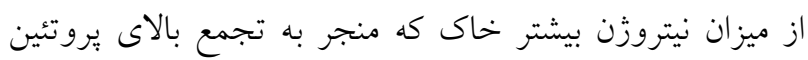

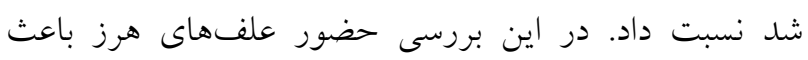

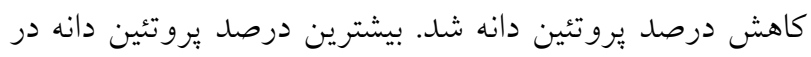
تيمار وجين دستى علفهاى هرز و كمترين درصد يروتئين دانه

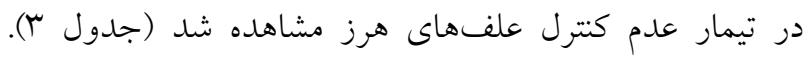
بنابراين مىتوان نتيجه كرفت كه تداخل علفهاى هرز علاوه

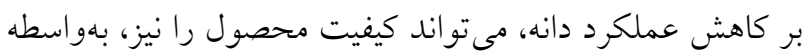
تغيير در تركيبات موجود در دانه نظير بروتئين دانه تحت تأثير

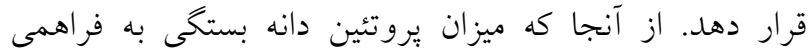

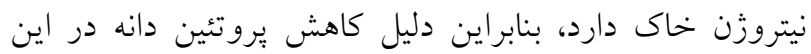
آزمايش را مىتوان به كاهش و تخليه نيتروزن خاك در اثر

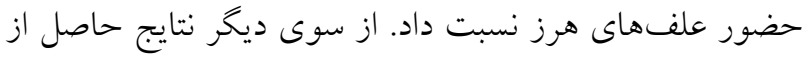

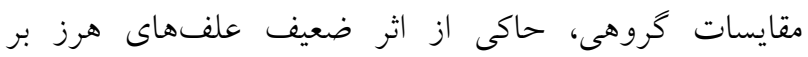

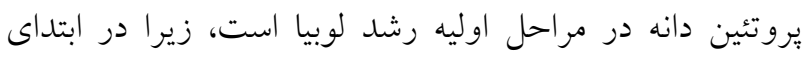




$$
\begin{aligned}
& \text { كاهش عملكرد نهايى دانه لوبيا شد. در صورتى كه كنترل اين كامل علفهاى هرز به طريق وجين دستى، بهدليل عملكرد بالا } \\
& \text { كياهان با هر روشى منجر به بهبود عملكرد دانه لوبيا قرمز شد براى منطقه آزمايش مناسبتر است. لازم بهذكر است عمل } \\
& \text { كه در بين روشهاى مورد تحقيق، كارآيى وجين دستى به و وجين دستى در سطوح كشت محدود و خرد كاربرد داشته و در } \\
& \text { مراتب برتر از علف كش هاى شيميايى بود. بهطور كلى تراكم سطوح كشت وسيع، كاربرد علف كش بنتازون مقرون بهصرفه } \\
& \text { كاشت بيشتر (در اين آزمايش مب بوته در مترمربع) و حذف اهو اهد بود. }
\end{aligned}
$$

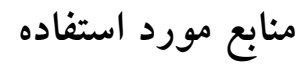

1. Ahmadi, A., M. H. Rashed mohsel, M. A. Baghestani meybodi, and M. Rostami. 2004. The effects of critical period of weed competition on yield, yield components and morphophysiological characteristics of dry bean (Phaseolus vulgaris 1.) cultivar, derakhshan. Entomology and Phytopatology 72(1): 31-49. (In Farsi).

2. Amirmoradi, Sh. and P. Rezvani Moghaddam. 2011. Effect of plant density and time of nitrogen application on morphological, phenological characteristics, yield and yield components of black cumin (Nigella sativa L.). Horticulture Science 25(3): 251-260. (In Farsi).

3. Arabi, M. and M. Saffari. 2015. The effect of weeding and plant density on yield and yield components of forage sorghum cultivars. Journal of Agronomy Sciences 5(10): 39-52. (In Farsi).

4. Asghari, S. R., M. Dadashi and M. T. Feyzbakhsh. 2018. Investigate the effect of plant density on yield and yield components of green pods in four pea cultivars in Gorgan region. Journal of Crop Production Research 10(2): 97115. (In Farsi).

5. Birhanu, A., T. Tadesse and D. Tadesse. 2018. Effect of inter- and intra-row spacing on yield and yield components of mung bean (Vigna radiata L.) under rain-fed condition at Metema District, northwestern Ethiopia. Agriculture \& Food Security 7(1): 84.

6. Burnsid, O. C., M. J. Weinse, B. J. Holder, S. Weisberg, E. A. Ristau, M. M. Johnson and J. H. Cameron. 1998. Critical period for weed control in dry bean (Phaseolus vulgaris). Weed Science 46: 301-306.

7. Chitband, A. A., S. A. Rashidi, S. Jahedi Pour, A. M. Mansouji and A. Amini. 2015. The effet of weed infested and weed checkon on growth properties and yeild of corn (Zea mays L.). Journal Management System 3(2): 127-142. (In Farsi).

8. Duncan, W. G., 1986. Planting pattern and soybean yield. Crop Science 26: 584-586.

9. Ehteshami, S. M., S. Soleimani and A. R. Pazoki. 2015. Effect of weed competition on morphophysiologic indices, yield and yield components of rapeseed (Brassica napus L.) cv. zarfam in varamin. Applied Field Crops Research (Pajouhesh \& Sazandehi) 109: 121-131. (In Farsi).

10. Elkoca, E., F. Kantar and H. Zengin. 2005. Weed control in lentil (Lens culinaris) in eastern Turkey. New Zealand Journal of Crop and Horticultural Science 33(3): 223-231.

11. Ghamari, H. and G. Ahmadvand. 2013. Effect of different periods of weed interference and weed control on height, yield and yield components of common bean. Journal of Crop Production and Processing 3(9): 71-80. (In Farsi).

12. Ghamari, H. and Gh. Ahmadvand. 2015. Effect of weed competition on seed's protein, seed's electrical conductivity and leaf's relative chlorophyll content of dry bean. Applied Field Crops Research (Pajouhesh \& Sazandegi) 107: 67-73. (In Farsi).

13. Ghanbari, A. A., and M. Taheri Mazandarani. 2003. Effects of sowing date and plant density on yield of spotted bean. Seed and Plant Improvment Journal 19(4): 483-496. (In Farsi).

14. Hashemi Jazi, S. M. and A. Danesh. 2003. Effect of row spacing and plant distances in row on grain yield and yield components in chiti bean cv. Talash. Iranian Journal of Crop Science 5(2): 155-162. (In Farsi).

15. Hohlberg, A. I. and D. W. Stanley. 1987. Hard-to-cook defect in black beans protein and starch considerations. Journal of Agricultural and Food Chemistry 35(4): 571-576.

16. Jafari, A. R., M. R. Ardakani, H. R. Darii, A. A. Ghanbari and M. N. Elkaee. 2010. Effect of plant spacing and plant density on yield and yield components of two white bean (Phaseolus vulgaris L.) promising lines in presence and absence of weeds. Iranian Journal of Field Crops Research 8(1): 34-41. (In Farsi).

17. Johnson, G. A., R. T. Hoverstal and R. E. Greenwald. 1998. Integrated weed management using narrow corn, row spacing, herbicides and cultivation. Agronomy Journal 90(1): 40-46.

18. Kavurmaci, Z., U. Karadavut, K. Kokten and A. Bakoglu. 2010. Determining critical period of weed-crop competition in faba bean (Vicia faba). International Journal of Agriculture and Biology 12: 318-320.

19. Khademhamzeh, H. R., M. Karimi, A. Rezaie and M. Ahmadi. 2004. Effect of plant density and planting date on 
agronomic characteristics, yield and yield components in soybean. Iranian Journal of Agriculture Science 35(2): 357-367. (In Farsi).

20. Khajehpour, M., 2005. Principles and Fundamentals of Crop Protection. Isfahan: Iranian Student Book Agency.

21. Kobraie, S., K. Shamsi, B. Rasekhi and A. Pazoki. 2010. The study of the effects of planting densitsy on morphological traits and seed quality in soybean (Glycine max L.). Plant and Ecosystem 6(23): 81-91. (In Farsi).

22. Koocheki, A. and Gh. Sarmadnia. 1999. Physiology of Crop Plants. Mashhad: Iranan Students Book Agency.

23. Latifi, N. and S. Navab Pour. 2000. The response of growth indices and seed yield of two pinto bean to row spacing and plant population. Iranian Journal of Agriculture Science 31(2): 353-362. (In Farsi).

24. Majnoun Hoseini, N. 2008. Grain Legume Production. Tehran: Iranian Students Book Agency.

25. Malik, C. S., C. J. Sowanton and T. E. Michaels. 1993. Interaction of white bean (Phaseolus vulgaris) cultivars, row spacing and seed density with annual weeds. Weed Science 41(1): 62-68.

26. Mousavi, S. K., A. Zand and M. A. Baghestani. 2005. Effects of crop density on interference of common bean (Phaseolus vulgaris L.) and weeds. Entomology and Phytopathology 73(1): 79-92. (In Farsi).

27. Noori, M., A. Nasrollahzadeh, M. H. Moosavi Anzabi and A. Valizadeghan. 2012. Evaluation of the effects of plant density and distance between rows on the yield and yield components in pinto bean (Phaseolus vulgaris 1.) in west azerbaijan. Journal of Agriculture Science Research 4(16): 117-128. (In Farsi).

28. Parvizi, S., R. Amirnia, B. Paseban Islam, A. Hasanzadeh Gorttapeh and Y. Raeii. 2011. Evaluation of different plant densities effects on rate and process of grain filling, yield and yield components in varieties of dry bean. Plant Production Science 18(1): 69-87. (In Farsi).

29. Rabiei, M. and M. Jeilani. 2014. Effect of row spacing and seed rate on grain yield, protein and agronomical traits on two cultivar of common bean (Phaseolus vulgaris 1.) in rasht region. Journal of Crop Improvment 16(2): 369380. (In Farsi).

30. Randhawa, M. A., Z. A. Cheema and M. Anjum. 2002. Influence of trianthema portulacastrum infestation and nitrogen on qualify of maize grain. International Journal of Agriculture and Biology 4(4): 513-514.

31. Rasoulzadeh, N., 2013. Effect of different nitrogen levels and weeds control on yield and agronomic characteristics of the wax bean in the city of Khoy. MSc thesis, Khoy: Islamic Azad University.

32. Rohrig, M. and H. Stutzel. 2001. Canopy development of chenopodium album in pure and mixed stands. Weed Research 41: 111-228.

33. Salehi, F. 2014. Effect of plant density on seed yield and its components in new red bean lines. Applied Field Crops Research (Pajouhesh \& Sazandegi) 103: 23-28. (In Farsi).

34. Shafaroodi, A., M. Zavareh, Gh. Peyvast and H. Darii. 2012. Effect of sowing date and plant density on grain yield and yield components in dry bean (Phaseolus vulgaris L.) landraces. Agricultural Science and Sustainable Production 22(3): 47-60. (In Farsi).

35. Silim, S. N. and M. C. Saxena. 1992. Compartive performance of some faba bean (Vicia faba) cultivars of contrasting plant types. The Journal of Agricultural Science 118(3): 325-332.

36. Vangessel, J. M., E. E. Schweizer, R. G. Wilson, L. J. Wiles and P. Westra. 1998. Impact of timing frequncy and frequency of in-row cultivation for weed control in dry bean (Phaseolus vulgaris). Weed Technol 12: 548-553.

37. Vazeri, M., A. Nasrollahzadeh, M. H. Moosavi and A. Valizadeghan. 2012. Effect of plant population on yield and yield components of soybean in different row spacing. Journal of Agriculture Science Research 5(5): 45-58. (In Farsi).

38. Williams, M. and J. L. Lindquist. 2007. Influence of planting date and weed interference on sweet corn growth and development. Agronomy Journal 99: 1066-1072. 


\title{
The Effect of Plant Density and Weed Growth Control Methods on Vegetative Traits and Yield of Red Beans
}

\author{
M. Roshdi ${ }^{*}$, M. Kazemalilou ${ }^{2}$ and S. Kazemalilou ${ }^{3}$
}

(Received: May 30-2020; Accepted: July 11-2020)

\begin{abstract}
Using a suitable planting density and proper weed control are important factors in achieving high yield in red beans. In order to investigate the effects of plant density and weed control on the growth and yield of red beans, a factorial experiment was conducted in three replications in completely randomized blocks at the Agricultural Research Center of Khoy, North-West of Iran in 2017-2018. Three planting densities (20, 25 and 30 plants $\left./ \mathrm{m}^{2}\right)$ and four weed control method strategies including uncontrolled, selective herbicide (Bentazone), manually controlled and non-selective herbicide application (Paraquat) were selected. The results showed that the interaction effect of planting density and weed control methods significantly affected the number of lateral branches, the distance of the first lateral branch from the ground, the main stem's diameter, the dry weight of the plant and seed yield. The highest seed yield (3391 kg/ha) was obtained in the planting density of 30 plants $/ \mathrm{m}^{2}$ and manually controlled weeding and the highest seed protein percentage (24.8\%) was obtained in the planting density of 20 plants $/ \mathrm{m}^{2}$ and manual-weeding method. The results of this study showed that the manual weed control method has a relative advantage over the other methods of weed control and the use of non-selective herbicide alone is not effective in controlling red bean weeds. The production of greatest seed yield with a population density of 30 plants $/ \mathrm{m}^{2}$ indicates a positive response of red beans to high plant densities.
\end{abstract}

Keywords: Herbicide, Protein percentage, Red bean, Stem diameter

1,2. Faculty Member and MSc. Student, Respectively, Department of Agronomy and Plant Breeding, Islamic Azad University, Khoy, Iran.

3. PhD Student, Department of Agriculture-Soil Science, Tabriz University, Tabriz, Iran.

*: Corresponding Author, Email: roshdi1349@yahoo.com 